\title{
PRINCIPALS' STRATEGIES FOR THE IMPROVEMENT OF STAFF PERSONNEL ADMINISTRATION OF SECONDARY SCHOOLS IN ENUGU NORTH EDUCATION ZONE, ENUGU STATE, NIGERIA
}

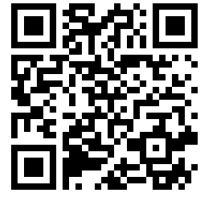

\author{
Chime Gladys Ozuluonye. ${ }^{1} \boldsymbol{\Delta}$, Ugwu Ifeanyichukwu ${ }^{2 \boldsymbol{\Delta}}$, Dr. Oparaji Israel Chijiuka \\ $3 \square$
}

1, 2, 3 Department of Educational Management and Policy Nnamdi Azikiwe University, Awka

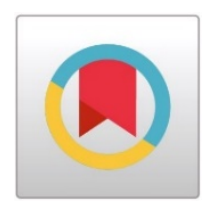

DOI: https://doi.org/10.29121/granthaalayah.v8.i5.2020.116

Article Type: Research Article

Article Citation: Chime Gladys Ozuluonye, Ugwu, Ifeanyichukwu, and Dr. Oparaji, Israel Chijiuka. (2020). PRINCIPALS' STRATEGIES FOR THE IMPROVEMENT OF STAFF PERSONNEL ADMINISTRATION OF SECONDARY SCHOOLS IN ENUGU NORTH EDUCATION ZONE, ENUGU STATE, NIGERIA. International Journal of Research GRANTHAALAYAH, 8(5), 322-328. https://doi.org/10.29121/granthaa layah.v8.i5.2020.116

Received Date: 15 May 2020

Accepted Date: 31 May 2020

Keywords:

Strategy

Staff Personnel Administration Secondary School

\section{ABSTRACT}

This study investigated the principals' strategies for the improvement of staff personnel administration of secondary schools in Enugu North Education Zone, Enugu state. The study has two purposes, and was guided by 2 research questions and two hypothesis. It adopted a descriptive research design. The population of the study consist 108 secondary school principals and 1,423 secondary school teachers in Enugu North Education Zone, Enugu state. Through multistage and simple random sampling, the sample size of 16 secondary school principals and 170 secondary school teachers were drawn. The instrument for data collection was a 20-item structured questionnaire. The questionnaire has two sections: section $\mathrm{A}$ for secondary school principals while section B is for secondary school teachers. The instrument were validated by three experts: two from Educational Management and Policy while the other one from Department of Measurement and Evaluation, all from faculty of education, Nnamdi Azikiwe University, after which they were subjected to test-retest on 15 secondary school principal and 15 secondary school teachers in Enugu West Education zone. Their scores were computed with Cronbach Alpha technique which yielded a reliability value of 0.75 which indicates that the instruments were valid. Data collected in this study were analyzed using arithmetic mean and standard deviation while the hypotheses were tested at 0.05 level of significance. Findings reveal that strategies adopted by secondary school principals in for the improvement of staff personnel administration include: involving teachers in decision making, teacher motivation, good leadership, assigning teachers with official responsibilities among others. It was also revealed that teachers were enhanced with s good leadership strategies from principals, motivation and engaging staff in re-training exercise.

\section{INTRODUCTION}

Education is regarded as one of the foremost and important instruments for change and development in the world today. Education is also a process of systematic training and instruction designed to transmit knowledge, acquire skills, potentials and abilities which enable an individual contribute significantly to the growth and development of his society and nation (Osakwe, 2006). Inline with this, Nwite and Adali (2012) believed that

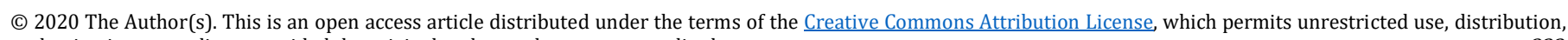
and reproduction in any medium, provided the original author and source are credited. 
Chime Gladys Ozuluonye, Ugwu, Ifeanyichukwu, and Dr. Oparaji, Israel Chijiuka

education by its nature is one of the foremost and important instruments for change and development in the world today. It is also the process of teaching, training and learning in schools or colleges to improve knowledge and develop skills through literacy programs. Morrison, Nyorere and Elekwa (2013) defined education as the preparation of individuals to fit into different roles and activities for the transformation of societies.

Education occurs formally in schools. It begins at the pre-primary and primary schools and climaxed at the secondary and tertiary levels of education. Secondary education being the context of this study is that level of education made available for learners after primary education. Jegede (2013) defines secondary education as that level of education that prepares students to be productive members of the society. In developed countries, secondary school is seen as the gateway to providing not only an educated citizenry but also a capable workforce.

Secondary education is crucial in both personal and national development. Secondary school level is the bridge between the primary and tertiary levels. It is the education children receive after primary education and before the tertiary stage within the range of 12 to 18 years (FRN, 2013). The broad goal of secondary education is to prepare the individual for useful living in the society and for higher education (FRN, 2004). Specifically, the secondary school system is geared towards catering for the differences in talents, opportunities and future roles, to provide technical knowledge and vocational skills necessary for agricultural, industrial, commercial and economic development (FRN, 2004). Secondary school should be able to provide quality teaching and learning. The importance of secondary education cannot be over emphasized since it has both consumer and producer status. This is because it consumes the product of primary schools and produces candidates for tertiary education. According to World Bank in Etim (2006), secondary education is now being recognized as the cornerstone of educational system in the 21st century.

It therefore means that quality secondary education is indispensable in creating a bright future for individuals and nations alike. In the secondary school system, the principals are important stakeholders that run the daily affairs of the school. The principal ensures that teachers (major personnel in the school administration) execute their primary duties for the achievement of educational goals. For this to be fulfilled, teachers are required to be highly committed to duties; which however depends on the administrative leadership strategies employed by the school principal. Because school principals cannot govern the school alone; their staff are important personnel that compliment their administrative duties. In fact, secondary education cannot be effective without activities of staff personnel administration. Staff personnel administration in schools is concerned with the development and effective utilization of human resources to achieve school objectives. The American Management Association in Ejeh and Okoro (2016) defined staff personnel administration as a responsibility of all those who manage people. It is part of management which is concerned with people at work and with their relationships within an enterprise. It applies not only to industry and commerce but to all fields of employment, secondary school inclusive.

Personnel administration, according to Obi (2003) can be viewed from different angles. One angle is to view personnel administration as a function or responsibility of every manager or supervisor who have people under him all working towards the achievement of desired goals. The second angle is that Personnel Management may be seen as a function in an organisation which is performed by a department, the personnel department. Sharing a similar view, Ajayi and Ayodele (2001:15) stated that "personnel administration is a basic function of management.

One of the most elaborate and comprehensive definition of staff personnel administration is that given by Flippo (1990:65) who discovered that there are two categories of functions: management and operative. Summing up these managerial and operative functions, Flippo defines personnel administration as the planning, organizing, directing, and controlling of the procurement, development, compensation, integration and separation of human resources to the end that individual, organizational and societal objectives are accomplished. Ogunsaju (2006) did not differ much from Flippo when he defined staff personnel administration as the effective mobilization of human resources based on appropriate recruitment, selection, training and placement of appointed staff in order to achieve the organizational set goals and objectives. He also viewed it as the effective utilization of human resources in an organization through the management of people and related activities

From these definitions, personnel administration may be viewed as a set of functions and activities used in the management of human resources in a non-discriminatory, affirmative, and effective manner for the benefit of the organization, the individual and the society. Nwachukwu in Ejeh and Okoro (2016) identified the traditional functions or activities with which staff personnel administration is concerned as: Staff recruitment, orientation, motivation and welfare, training and development, manpower planning, job analysis, health and safety, wages and salary administration, industrial relation, collective bargaining, discipline, performance appraisal, personnel audit, employee communication, human resource research and employee retirement.

In fact, personnel administration in schools are worth commendable for their tireless efforts towards ensuring that manpower recruited into secondary schools are trained to be worthy tools for the success of education. Though 
Principals' Strategies for The Improvement of Staff Personnel Administration of Secondary Schools in Enugu North Education Zone, Enugu State, Nigeria

some lapses abound among staff personnel as they go alone in their administrative duties, these lapses according to Chidi, Lucky, Ikechukwu (2019) range from lateness to duty, exhibiting poor relationship, indiscipline, poor communication, absenteeism and other forms of misconduct affecting secondary schools. Uzoechina and Nwankwo (2016) also observed that the increased rate of truancy, lateness and general poor job performance of teachers, coupled with the overt negative attitudes of teachers, are issues of major concern affecting secondary schools.

These lapses call for improvement of staff personnel administration; however, improvement cannot just take place without thinking of better strategies that may be adopted. Strategy has been successful in organizations that purposefully have a goal to achieve. By by definition, strategy is a plan of action. Freedman (2015) asserts that strategy involves setting goals, determining actions to achieve the goals, and mobilizing resources to execute the actions. To freedman, a strategy describes how the ends (goals) will be achieved by the means (resources). Strategy can be intended or can emerge as a pattern of activity as the organization adapts to its environment. It involves activities such as strategic planning and strategic thinking. Freedman's definition of strategy is not far from Kvint (2009) who stated that strategy is a system of finding, formulating, and developing a doctrine that will ensure longterm success if followed faithfully. Some strategies for improvement of staff personnel administration of secondary schools has been enumerated by some scholars.

Omemu (2017) identified some of the strategies to be adopted by secondary school principals to include; establishing and communicating high expectations, developing clear behavioural rules and procedures and making these expectations for stakeholders, parents and community, engaging school and community wide commitment to establishing and maintaining appropriate students' behaviour in schools and at school sponsored events. They also include encouraging teachers to handle all classroom disciplinary problems that they can, increasing visibility and informal involvement in everyday life of the school, increasing personal interactions with students by taking interest in their plans and activities and arranging for appropriate staff development activities. Similarly, Nwite and Eze (2016) mentioned effective communication and communication skills; while Omemu (2017) and Pandey (2017) identified principals' administrative strategies necessary for teachers' commitment as adopting varieties of instructional leadership strategies, teacher evaluation, monitoring and supervision strategies, staff-personnel strategies, student-personnel strategies, utilizing various organizing, planning, coordinating and budgeting strategies, among others. Additionally, the instructional leadership roles of principals include setting clear goals, managing the curriculum, monitoring lesson plans, staff motivation, good relationship with staff and evaluating teachers' performance. A skilled principal can ensure better academic supervision of the teachers with quality feedback to enable them to learn better strategies of classroom management (Akomolafe, 2012; Omemu, 2017).

Staff personnel plays significant roles in assisting secondary school principals in administrative duties because left for them (principals) alone, they cannot work for the actualization of the school goals and objectives. Staff personnel administrators are needed to help school principals oversee sensitive aspects of the school administration. These aspects include security, welfare, admission and registration, supervision, assessment, extracurricular activities, religion and others. Little wonder the aspects of human resource in this aspect are referred to as staff personnel resource. They help the school principal actualize institutional goals and remain law abiding to the ethics that guide the school.

However, there are cases where staff personnel derailed from their ethical conducts such as display of favoritism, poor communication to the school manager and to students, absenteeism, gossip and lots more. These observed lapses calls for improvement of existing staff among secondary schools. Improvement in this case requires the application of some techniques of strategies to get it right. If this tide is not stemmed, the future of secondary education in Enugu State is like to be adversely affected. This study is therefore expected to address this shortcoming.

The general purpose of this study is to identify strategies for the improvement of staff personnel administration in secondary schools in Enugu North Education zone. Specifically, the study sought to;

1) Find out secondary school principal strategies for improvement of staff personnel administration in Enugu Education zone

2) Find out teachers opinions on secondary school principals strategies towards staff personnel administration in Enugu education zone.

3) Accordingly, two research questions guided the study

4) What are secondary school principals' strategies for improvement of staff personnel administration in Enugu education zone?

5) What are teachers opinions on principals strategies towards staff personnel administration in Enugu education zone

International Journal of Research -GRANTHAALAYAH 
H0: There is no significant difference between principals' strategies and improvement of staff personnel administration.

H0: There is no significant relationship between teachers opinion and principals strategies towards staff personnel administration.

\section{MATERIALS AND METHODS}

This study adopted a survey research design. A survey design according to Nwaogu (2015) is one in which a group of people is studied by collecting and analyzing data from only a few people or items considered to be representatives of the entire group. The survey design therefore is appropriate for this study because opinions of secondary school principals and teachers in Enugu North education zone are sought regarding principals strategies for improving staff personnel administration in secondary schools. The area of study for this research is Enugu North Education Zone. Enugu north education zone comprise local governments to include Igbo-Eze-North, Igbo-Ezesouth, Udenu, Nsukka, Igbo Etiti and Uzo-Uwani. There are 108 public secondary schools in Enugu North education zone. This makes the area suitable for this study. The population of the study is made up of 108 secondary school principals and 1,423 secondary school teachers among the 108 public secondary schools in Enugu North Education Zone as at December, 2019 (Source: Post primary Schools Management Board, Enugu). The researcher used multi stage sampling technique to select sample respondents for this study. The researcher selected 4 local governments out of 6 that in Enugu North education zone and from these four selected local governments, four schools were selected in each of them making a total of 16 secondary schools selected. Purposively, the researcher selected all the 16 principals of these secondary schools and through simple random sampling selected 170 number of secondary schools teachers through balloting without replacement. Among these teachers, 90 were from senior secondary section while 80 from junior secondary section. The instrument used in carrying out this research was a structured questionnaire with 20 items used to elicit information from the respondents. The instrument was validated by three experts, two from department of Educational Management and policy and one from measurement and evaluation, all from Faculty of Education, Nnamdi Azikiwe University, Awka. In order to establish the reliability, a test-retest was used. The instrument was administered to a sample of 15 principals and 15 teachers in Enugu West education zone. The data derived were analyzed using Crombach Alpha which yielded a co-efficient value of 0.75 ; this was considered high enough to confirm that the instrument were reliable. The questionnaire items were distributed with the help of six trained research assistants. The exercise took three weeks. A total of 170 questionnaire items distributed, only 154 were fully returned. The data collected were analyzed using arithmetic mean and standard deviation.

\section{RESULTS AND DISCUSSIONS}

Research Question 1: What are Secondary School principals Strategies for improvement of Staff Personnel Administration in Enugu North Education Zone?

Table 1: Response of Secondary School Principals on Strategies for improvement of Staff Personnel Administration.

\begin{tabular}{|l|l|c|c|c|c|c|c|c|c|}
\hline S/N & Items & SA & $\mathrm{A}$ & $\mathrm{D}$ & $\mathrm{SD}$ & $\mathrm{N}$ & $\overline{\mathrm{X}}$ & Std. & Dec. \\
\hline 1 & Involving teachers in decision making & 7 & 5 & 1 & 3 & 16 & 3.00 & 1.15 & $\mathrm{~A}$ \\
\hline 2 & Ensuring cordial relationship between principals and teachers & 7 & 9 & 0 & 0 & 16 & 3.44 & .512 & $\mathrm{~A}$ \\
\hline 3 & Democratic leadership style & 5 & 8 & 3 & 0 & 16 & 3.13 & .719 & $\mathrm{~A}$ \\
\hline 4 & Autocratic leadership style & 4 & 3 & 5 & 4 & 16 & 2.44 & 1.15 & $\mathrm{D}$ \\
\hline 5 & Laisser-faire leadership & 0 & 0 & 10 & 6 & 16 & 1.63 & .50 & $\mathrm{D}$ \\
\hline 6 & Motivating teachers through verbal praise & 5 & 7 & 3 & 1 & 16 & 3.00 & .89 & $\mathrm{~A}$ \\
\hline 7 & Engaging teachers in re-training exercise & 6 & 8 & 1 & 1 & 16 & 3.13 & .96 & $\mathrm{~A}$ \\
\hline 8 & Counseling of teachers & 8 & 5 & 1 & 2 & 16 & 3.19 & 1.05 & $\mathrm{~A}$ \\
\hline 9 & Assigning official duties to teachers & 6 & 9 & 0 & 1 & 16 & 3.25 & .78 & $\mathrm{~A}$ \\
\hline 10 & Discipline of teachers & 4 & 2 & 6 & 4 & 16 & 2.38 & 1.15 & $\mathrm{D}$ \\
\hline
\end{tabular}


Principals' Strategies for The Improvement of Staff Personnel Administration of Secondary Schools in Enugu North Education Zone, Enugu State, Nigeria

The result in table 1 shows mean scores and standard deviation of secondary school principals' strategies for improvement of staff personnel administration in Enugu North Education Zone. The result revealed that items 1, 2, 3,6,7,8 \& 9 are principals' strategies for improvement of staff personnel administration with their respective mean scores as 3.00, 3.44, 3.13, 3.00, 3.13, 3.19 and 3.25. This is so because; the mean scores are greater than the criterion mid-point of 2.50, while items 3,4 and 10 with respective mean scores of 2.44, 1.63 and 2.38 are not secondary school principals' strategies for improvement of staff personnel administration. This is as a result of their mean scores lower than the criterion mid-point of 2.50.

Research Question 2: What are teachers' opinions on principals' strategies towards staff personnel administration in Enugu education zone?

Table 2: Response on teachers on principals' strategies towards personnel administration

\begin{tabular}{|c|c|c|c|c|c|c|c|c|c|}
\hline $\mathrm{S} / \mathrm{N}$ & Items & SA & $A$ & D & SD & $\mathrm{N}$ & $\bar{X}$ & STD & Dec \\
\hline 1 & $\begin{array}{l}\text { Involving a teacher in decision making enhances his } \\
\text { commitment in administrative duties }\end{array}$ & 52 & 69 & 17 & 14 & 154 & 3.01 & .93 & A \\
\hline 2 & $\begin{array}{l}\text { You feel at home when in your work when the principal } \\
\text { extends his cordial relationship to you }\end{array}$ & 47 & 56 & 28 & 23 & 154 & 2.83 & 1.03 & A \\
\hline 3 & $\begin{array}{l}\text { As a staff, your principal is approachable because he is } \\
\text { democratic }\end{array}$ & 73 & 55 & 11 & 15 & 154 & 3.21 & .95 & A \\
\hline 4 & You do your work better when your principal is authocratic & 21 & 15 & 68 & 50 & 154 & 2.05 & .99 & $\mathrm{D}$ \\
\hline 5 & $\begin{array}{l}\text { As a teacher, you had enjoyed administration in your school } \\
\text { especially when it your principal is lazy }\end{array}$ & 10 & 17 & 73 & 54 & 154 & 1.89 & .84 & $\mathrm{D}$ \\
\hline 6 & $\begin{array}{l}\text { Verbal praise from your principal encourages you towards } \\
\text { administrative duties }\end{array}$ & 67 & 54 & 10 & 23 & 154 & 3.07 & 1.05 & A \\
\hline 7 & $\begin{array}{l}\text { You are abreast with your principal when he engages you on } \\
\text { re-training exercise }\end{array}$ & 71 & 58 & 16 & 9 & 154 & 3.24 & .86 & A \\
\hline 8 & $\begin{array}{l}\text { You recall and maintain ethics of your profession when } \\
\text { privately counseled by your principal }\end{array}$ & 72 & 64 & 7 & 11 & 154 & 3.24 & .91 & A \\
\hline 9 & $\begin{array}{l}\text { Assigning responsibilities to you adds more experience to } \\
\text { your administrative duties }\end{array}$ & 46 & 55 & 21 & 32 & 154 & 2.75 & 1.09 & A \\
\hline 10 & $\begin{array}{l}\text { When you are disciplined for an offence, it demoralizes your } \\
\text { zeal to continue with duties. }\end{array}$ & 51 & 44 & 34 & 25 & 154 & 2.79 & 1.08 & A \\
\hline
\end{tabular}

The result in table 2 shows mean scores and standard deviation of teachers' opinions on principals' strategies towards staff personnel administration in Enugu education zone. The result revealed that all the items except items 4 and 5 are teachers' opinion on principals' strategies towards staff personnel administration in Enugu education zone. This is so because their mean scores are greater than the criterion mid-point score of 2.50 .

\section{Testing of Hypothesis}

Hypothesis 1: There is no significant difference between principals strategies and improvement of staff personnel administration.

Table 3: t-test for the significant difference between principals with or without many years of experience on strategies for improvement of staff personnel administration.

\begin{tabular}{|l|c|c|c|c|c|c|c|c|}
\hline Source & Experience & $\mathrm{N}$ & Mean & Std & $\mathrm{t}$ & $\mathrm{df}$ & $\mathrm{p}$-value & Decision \\
\hline & With & 10 & 3.35 & .481 & & & & \\
\hline Principals & & & & & 5.101 & 14 & .000 & Significant \\
\hline & Without & 6 & 2.03 & .531 & & & & \\
\hline
\end{tabular}


Result in table 3 shows that there is a statistical significant difference between secondary school principals with and those without many years of experience on strategies for improvement of staff personnel administration. This is so because, the $p$-value $=.000$ is less than the level of significant $=0.05$. The researcher therefore rejected the null hypothesis and concluded that, there is a statistical significant difference between principals with and those without many years of experience on strategies for improvement of staff personnel administration.

Hypothesis 2: There is no significant relationship between teachers opinion and principals strategies towards staff personnel administration.

Table 4: t-test for the significant difference between opinion of junior and senior secondary school teachers on principals' strategies towards staff personnel administration.

\begin{tabular}{|l|c|c|c|c|c|c|c|c|}
\hline Source & Position & $\mathrm{N}$ & Mean & Std & t & $\mathrm{df}$ & $\mathrm{p}$-value & Decision \\
\hline & Senior & 83 & 2.92 & .555 & & & & \\
\hline Teachers' & & & & & 2.409 & 152 & .017 & Significant \\
\hline & Junior & 71 & 2.68 & .665 & & & & \\
\hline
\end{tabular}

Result in table 4 shows that there is a statistical significant difference between opinion of junior and senior secondary school teachers on principals' strategies towards staff personnel administration. This is so because, the $\mathrm{p}$-value $=.017$ is less than the level of significant $=0.05$. The researcher therefore rejected the null hypothesis and concluded that, there is a statistical significant difference between opinion of junior and senior secondary school teachers on principals' strategies towards staff personnel administration

The results as presented in table one show that strategies adopted by secondary school principals in staff personnel administration include involving teachers in decision making, cordial relationships, democratic leadership, motivation, engagement of teachers in -retraining exercise, counseling and assigning official duties to teachers. Some of these findings were in line with Pandey (2017) who identified leadership, staff motivation, good relationship with staff and evaluating teachers performance as strategies adopted by principals of secondary schools in staff improvement.

The result as presented in table two enumerated opinions of teachers and strategies adopted by their principals towards staff personnel administration. Teachers opined that their involvement in decision making, working with their principal who exhibit good relationship, enhances their commitments towards duty. It was also revealed that democratic and motivating principals and principals' that encourages re-training of its staff including counseling, one who assigns responsibilities to teachers; all enhances teachers' commitment towards their primary assignments in school. These opinions agree with the findings of Egwu (2012) who saw teachers enumerate their feelings on principals strategies to include encouraging teachers for in-service training and good relationship with staff. Pigford (2007) added that principals seeking the welfare of their staff, organizing re-training workshop, creating collegial relationships with teachers and accommodating different teachers-personality styles were strategies used by principals of schools for the improvement of staff and promotion of healthy relationship in the school.

Result from table 3, shows that there was a statistical difference between principals with many years of experience and those without years of experience on strategies they adopt in staff improvement. This was indicated by the P-value $=.000$ which is less than the level of significance 0.05 . The null hypothesis is therefore rejected. This means there is a significant difference between principals with years of experience and those without years of experience on strategies for improving staff personnel administration.

Results from table 4 show that p-value was .017 is less than the level of significance which is 0.05 . The null hypothesis was rejected indicating a significant difference between opinion of school teachers on principals strategies towards staff personnel administration.

\section{CONCLUSION AND RECOMMENDATIONS}

Based on the findings of this study, it was recommended as follows;

1) Principals of secondary schools should strive to maintain strategies that carry their staff along as this is significant in enhancing the growth of teaching and learning in secondary schools. 
Principals' Strategies for The Improvement of Staff Personnel Administration of Secondary Schools in Enugu North Education Zone, Enugu State, Nigeria

2) Principals should initiate and maintain good leadership styles in their schools to enable teachers fully participate in administrative activities in the school with all sincerity.

3) Government should as well maintain their motivation to teachers by constantly paying them their salaries as this will help teachers be good followers of their respective principals.

\section{SOURCES OF FUNDING}

None.

\section{CONFLICT OF INTEREST}

None.

\section{ACKNOWLEDGMENT}

None.

\section{REFERENCES}

[1] Ajayi, A. \& Ayodele, H. (2001) Fundamentals of educational management. Ado-Ekiti: Greenline Publishers.

[2] Akomolafe, C.O. (2012). A comparative study of principals' administrative effectiveness in public and private secondary schools in Ekiti State, Nigeria. Journal of Education and Practice, 3(3):39-45.

[3] Chidi, N., Lucky, A. J., Ikechukwu, O. H. (2019). Personnel Management Practices adopted by Principals in Administration of Secondary Schools in Awka Education Zone, Anambra State, Nigeria. Educational Process: International Journal, 8(1), 32- 43.

[4] Ejeh, E. I., and Okoro, P. (2016). Evaluation of staff personnel administration in tertiary institution in south Eastern Nigeria from 2007 to 2012. Greener Journal of Educational Research, 6(6) 213-222.

[5] Federal Republic of Nigeria (2013). National Policy on Education. Lagos, NERDC.

[6] Flippo, E. (1990) Personnel management: Kogukusha: McGraw.

[7] Freedman, L. (2015). Strategy: a history. Oxford: Oxford University Press.

[8] Kvint, V. (2009). The Global Emerging Market: Strategic Management and Economics. Routeledge.

[9] Nwite, 0 and Eze, B. O. (2016). Mechanism for improving the managerial communication skills of school principals for effective school administration in Nigeria. British Journal of Education, 4 (7) 67-81.

[10] Nworgu, B.G. (2015). Educational research: basic issues and methodology (3rd ed.) Enugu: University Trust Publisher.

[11] Obi, E. (2003). Educational management: Theory and practice. Enugu: Jamoe Enterprises, Nigeria

[12] Ogunsaju, T.O. (2006). Human capital management for effective corporate governance. Paper presented, at a. Workshop titled: Corporate Governance for Sustainable National Development. April 2006.

[13] Omemu, F. (2017). Relationship Between Principals Administrative Strategies and Student Disciplinary Problems in Secondary School, Bayelsa State. Journal of Education and Practice, 3(13)100-104.

[14] Pandey, P. (2017). The need for administrative effectiveness of the principals at secondary level. International Journal of Advanced Education and Research, 2(3) 68-70. 